\title{
Targeting Multiple Management Objectives in Sustainable Fisheries
}

\author{
Eric A. L. $\mathrm{Li}^{1}$ \\ ${ }^{1}$ Department of Statistics and Actuarial Science, University of Hong Kong, Hong Kong \\ Correspondence: Eric A. L. Li, Department of Statistics and Actuarial Science, University of Hong Kong, \\ Pokfulam Road, Hong Kong. Tel: 852-3917-8142. E-mail: ericli@saas.hku.hk
}

Received: May 30, 2014

Accepted: July 2, 2014 Online Published: August 29, 2014

doi:10.5539/jms.v4n3p54

URL: http://dx.doi.org/10.5539/jms.v4n3p54

\begin{abstract}
Modern fisheries management must balance between return (economic value) and risk (harvest uncertainty and stock collapse). Management tools should target multiple simultaneous management objectives. These include output, number of seasons, total stock value and its uncertain fluctuations. I provide a stylized fishery model for simulating the outcomes of these competing management objectives under various regulatory and market environments. Results show that these objectives need not be mutually exclusive. They can be traded off gradually, quantitatively and transparently. The trade-offs involve profit and output versus job provision, employment security, stock conservation and less-risky harvesting. The pursuit of higher return must balance against the risk of stock collapse and harvest fluctuations.
\end{abstract}

Keywords: marine reserve, fisheries management, simulations, trade-off.

\section{Fisheries Management Objectives}

Traditional fisheries management typically concerns the health of the fish stock, in particular, its size. For example, the Ecological Quality Objective (EcoQO) for the North Sea demersal fish community (Greenstreet et al., 2011) is the state-of-the-art development in this regard. It identifies size-based metrics as the most effective indicators of the state of the ecological community. Such metrics are also sensitive to environmental influence. The large fish indicator (LFI) is one such indicator that is sensitive to fishing-induced change. This complex relationship underscores the need for operational theoretical size-resolved multispecies fish community models to support management towards broader ecosystem objectives.

At the moment, quantitative fish stock assessment techniques are far in advance of successful fisheries management applications. For example, techniques such as stock synthesis (SS) (Methot Jr. \& Wetzel, 2013) adopt a statistical age-structured population modeling framework. It is highly scalable from data-weak situations where it operates as an age-structured production model, to complex situations where it can flexibly incorporate multiple data sources and biological/environmental processes. Despite the advances in these techniques, there have been relatively few successful applications in management practice. Hilborn (2007) holds a more optimistic view. Besides using marine-protected areas as the central tool of a new approach to rebuilding the marine ecosystems of the world, he argues that much can also be learned from examples of successfully managed fisheries: "These lessons are stopping the competitive race to fish by appropriate incentives for fishing fleets and good governance. The major tool of resetting incentives is granting various forms of dedicated access, including community-based fishing rights, allocation to cooperatives, and individual fishing quotas. Many of the failed fisheries of the world occur in jurisdictions where central governments are not functional, and local control of fisheries is an essential part of the solution." (Hilborn, 2007, p. 296) The essential elements of these successfully managed fisheries are economic sustainability and the cooperative nature of the fishery industries. For example, BenDor et al. (2009) argue that this is particularly important in rural coastal areas where the fishing industry is often a dominant employer. They analyze the interactions between economic and ecological dynamic systems using a multi-agent dynamic model of fishery management. Multiple agents (fishers) harvest multiple fish species and adapt the amount and allocation of their effort to their value functions. These are given as net profits of the fish harvest sold for a market price. Their model suggests that competitive fisher behaviors lead to a decline of all fish stocks, as well as their profits. On the other hand, cooperative fisheries that jointly set sustainable limits for total harvest and effort can stabilize the fish stocks and profits at significantly higher levels. These then lead to a continuous accumulation of capital for all fishers. 
I argue that, for modern fisheries managers, their first-and-foremost objectives must be to ensure that (1) the stock is sustainably harvested in a biological sense; (2) the stock is optimally harvested in an economic sense; and (3) all stakeholders are to be treated equally and fairly. For (1) and (2), the necessary hurdles must include a sustainable stock size, the total derivable economic value from the stock, and the periodic harvest output, effort and profit. For (3), the hurdles are less well-defined. However, it is reasonable to demand that they include the chances or probability of achieving the total derivable economic value; the number of harvest seasons required; and the variability of this random total derivable economic value. All of them affect to a large extent the livelihood of the parties employed by or involved in the fishery: fishermen, managers, scientists and coastal communities. Achieving these objectives often have the added bonus of ameliorating the economic consequences of a stock assessment error.

The economic value of the stock supports the fishermen, the crew, the community, the managers and the science. The variability or uncertainty of economic return affects those employed by the fishery. Workers have to be laid off in a low season, only to be hired back in a high season. Variability affects the stability of livelihood. Furthermore, the notion of maintaining a certain stock size is popular with various legislation (Lauck et al., 1998, p. S76). Thus, finding the probability that this could be achieved is important. In economics, we might similarly wish to maximize the probability of achieving certain levels of fishery economic value and the number of seasons required to achieve them. This is because they affect the long-term planning of the investment and construction of amenities and facilities in the community.

There are other non-economic but stock-related objectives. A complete list of these has been compiled by Novaczek (1995), Hockey and Branch (1997, p. 377) and Lauck et al. (1998, p. S77).

This paper attempts to target some common fisheries management objectives:

(1) achieving sustained and optimal levels of periodic harvest effort, output and profit;

(2) maximizing the total expected fish stock value; the probability of achieving this or certain pre-specified levels of total stock value; and the sustainable stock size;

(3) minimizing the fluctuations in the total expected stock value; and the number of harvest periods to achieve the maximum total expected stock value.

I lay out the rest of the article as follows. The next section explains the model that runs simulations on the above management objectives. Section 3 then conducts a series of simulation experiments over these competing management objectives. I will highlight the inherent conflict and trade-off among these objectives. Section 4 concludes with policy implications.

\section{The Simulation Model}

My simulations are based on an erstwhile model (Li, 2000). There are two assumptions:

(1) The fishery is cooperative, profit-maximizing, license-restricted, poaching-free, maintains a biologically sustained stock, and is mutually agreed to a legally binding division of harvest profits through a successfully negotiated internal transfer payment system (Munro 1996); and

(2) Harvest costs and demand for the harvest output are governed by deterministic market conditions and there exists no uncertainty regarding stock size, harvestability, and market demand. The unit harvest effort cost and the perfectly competitive harvest output price are both constant.

Finally, the model also assumes a stable production function. The optimal harvest solution for the fleet is obtained by maximizing profit over harvest effort, subject to the harvest production equation and a stock sustainability requirement that links output to effort.

Next, a certain percentage of total harvestable area is designated as marine reserve or no-take zone where all commercial harvest activities are banned. Suppose the marine reserve is strictly monitored and enforced and that the stock distribution over the total harvestable area is perfectly homogeneous. A perfectly homogeneous stock distribution assumption implies that the percentage of biomass inside the reserve and the percentage of biomass in the harvestable area are to be maintained at all times. Thus the biomass density $\left(\mathrm{kg} / \mathrm{m}^{3}\right)$ throughout the reserve and harvestable area is constant. Therefore, when the harvestable area is being exploited, there will be a net migration of individuals (biomass) out of the reserve into the harvestable area. Also, the percentage of the reserve stock foraging outside the reserve area is the same as that of non-reserve stock foraging inside the reserve area and exchange between the two over time is consistent. Consequently, harvest will be a function of non-reserve stock and the intensity of fishing effort only.

Suppose that a fish stock is never going to collapse, the total value that can be derived from the fishery is the sum 
of all sustained future periodic harvest profits discounted to the present. When the future prospect of a stock collapse poses a relevant threat, the assumption of a long time frame is no longer valid. Moreover, the fishery value that can be derived from harvest profits will also depend on when the collapse is likely to occur, and the timing of the collapse should also involve the interaction of effort and population dynamics.

Once the stock experiences an unexpected collapse, it can never recover to an economically viable level for sustainable harvest. The model assumes that a marine reserve can mitigate such a collapse. The mathematics shows that the probability of stock collapse decreases with the proportion of the total harvestable area designated as a marine reserve.

My simulation model, based on Li (2000), is a multi-period, marine-reserve-adjusted, stochastic-stock-size Schaefer model. It examines the relationship between the risk of stock collapse and the return of fishery economic value by using optimum harvesting and a marine reserve as the twin tools of management control. Next, I run simulations on this model using a stylized fishery. My objective is to show that the reserve size and harvest effort can target some common management objectives, in addition to maximizing fishery economic value.

The main equations of the model are summarized in Appendix A (Li, 2000). My simulations are conducted by treating the model as an application package with the input parameters, control variables and output values detailed in the following Table 1.

Table 1. Input parameters, control variables and output values for the simulation model

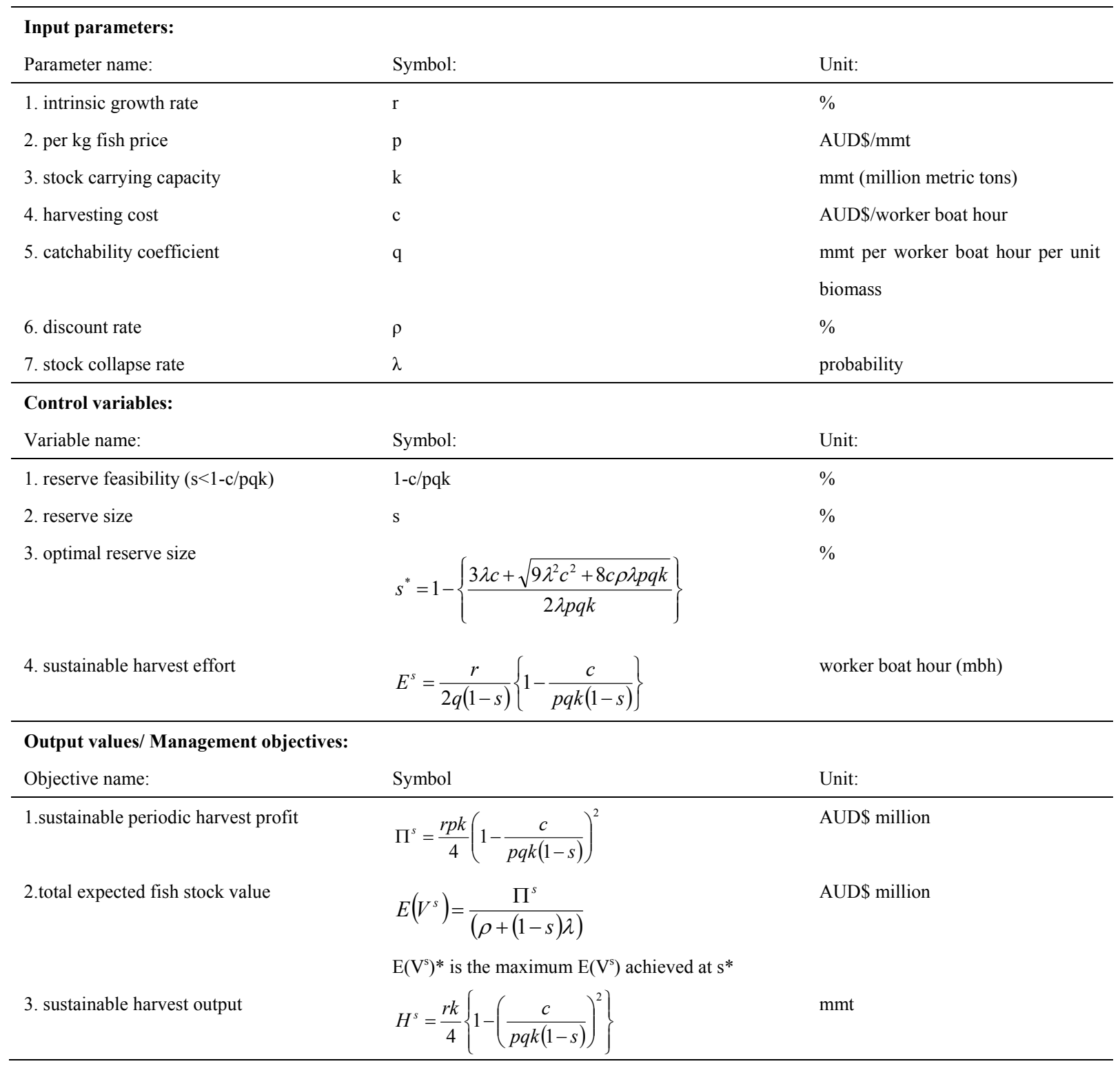




\begin{tabular}{lll}
\hline 4. sustainable stock size & $X_{2}^{s}=\frac{k}{2}\left\{1+\frac{c}{p q k(1-s)}\right\}$ & mmt \\
5.time (no. of seasons) to $\mathrm{E}\left(\mathrm{V}^{\mathrm{s}}\right)$ & $t=\frac{1}{\rho} \ln \left(\frac{\rho+(1-s) \lambda}{(1-s) \lambda}\right)$ & harvest periods t \\
6.prob. of time to $\mathrm{E}\left(\mathrm{V}^{\mathrm{s}}\right)$ & $\mathrm{t}^{*}$ is the $\mathrm{t}$ that reaches $\mathrm{E}\left(\mathrm{V}^{\mathrm{s}}\right)^{*}$ & \\
7.prob. achieving $50 \% \mathrm{E}\left(\mathrm{V}^{\mathrm{s}}\right)^{*}$ & $P(t)=\left(\frac{(1-s) \lambda}{(1-s) \lambda+\rho}\right)^{\frac{(1-s) \lambda}{\rho}}$ & probability \\
8.prob. achieving $75 \% \mathrm{E}\left(\mathrm{V}^{\mathrm{s}}\right)^{*}$ & $P\left(50 \% E\left(V^{s}\right)^{*}\right)=\left(\frac{\Pi^{s}-50 \% E\left(V^{s}\right) * \rho}{\Pi^{s}}\right)^{\frac{(1-s) \lambda}{\rho}}$ & probability \\
9.prob. achieving $100 \% \mathrm{E}\left(\mathrm{V}^{\mathrm{s}}\right)^{*}$ & $P\left(75 \% E\left(V^{s}\right)^{*}\right)=\left(\frac{\Pi^{s}-75 \% E\left(V^{s}\right)^{*} \rho}{\Pi^{s}}\right)^{\frac{(1-s) \lambda}{\rho}}$ & probability \\
10.prob. achieving $125 \% \mathrm{E}\left(\mathrm{V}^{\mathrm{s}}\right)^{*}$ & $P\left(E\left(V^{s}\right)^{*}\right)=P\left(t^{*}\right)=\left(\frac{\Pi^{s}-E\left(V^{s}\right) * \rho}{\Pi^{s}}\right)^{\frac{(1-s) \lambda}{\rho}}$ & probability \\
11.prob. achieving $150 \% \mathrm{E}\left(\mathrm{V}^{\mathrm{s}}\right)^{*}$ & $P\left(125 \% E\left(V^{s}\right)^{*}\right)=\left(\frac{\Pi^{s}-125 \% E\left(V^{s}\right) * \rho}{\Pi^{s}}\right)^{\frac{(1-s) \lambda}{\rho}}$ & probability \\
& $P\left(150 \% E\left(V^{s}\right)^{*}\right)=\left(\frac{\Pi^{s}-150 \% E\left(V^{s}\right) * \rho}{\Pi^{s}}\right)^{\frac{(1-s) \lambda}{\rho}}$ & probability
\end{tabular}

The model input parameters include the intrinsic growth rate $r$, per $\mathrm{kg}$ price $p$, stock carrying capacity $k$, per worker-boat-hour harvest $\operatorname{cost} c$ and the fleet's catchability coefficient $q$. These are all parameters in the original Schaefer model (1954). The market discount rate $\rho$ and the Poisson stock discount rate $\lambda$ are from Li's model. The first control variable is the marine reserve size $s$ that is set by the regulators. There is a feasibility requirement on the $s$ so that the model is implementable. That is, $s$ must produce sensible (non-negative and finite) solutions for harvest output, effort and profit. The second control variable is harvest effort $E$, although its level is always set to maximize total harvest profit and the fishery's economic value. This is because fishers will fully exploit the regulations once they are laid down, whether the regulations are on quota, fishing area, limited season or gear used. In this paper we assume no irregular or illegal activities such as poaching. Consequently, $s$ and $E$ as control variables for targeting management objectives.

The model outputs represent various management objectives. Traditionally, they include the sustainable periodic harvest profit, harvest output, and the sustainable stock size. In this paper, I add the total expected stock value; the expected time (number of harvest periods) and the probability of achieving the total expected stock value; and the respective probabilities of achieving $50 \%, 75 \%, 100 \%, 125 \%$ or $150 \%$ of total expected stock value.

\section{Simulation Results and Discussions}

\subsection{Simulating Maximum Stock Value by Comparative Statics}

Simulation results of 8 different scenarios for a stylized fishery are summarized in Table 2. The 8 scenarios include the base scenario and 7 other scenarios. In each scenario exactly one parameter has a different value from the base scenario. In economic analysis, the technique is known as comparative statics. It measures the change in optimum values of the objective function and of the control variables when exactly one parameter of the model experiences a change. In the base scenario, the stock intrinsic growth rate $r$ is $1 \%$ p.a., per $\mathrm{kg}$ fish price $p$ is AUD $\$ 10$ ( $\$ 10$ Australian dollars), the stock carrying capacity $k$ is 1 million metric tons (or $1 \mathrm{mmt}$ ), the harvesting cost $c$ is AUD\$50 per worker per boat per hour (including all food, fuel, bait and tackle, equipment hire, service and maintenance), the fleet's harvesting productivity (the catchability coefficient $q$ ) is $1 \times 10^{-7} \mathrm{mmt}$ per worker boat hour per mmt biomass. This implies that, for example, given a biomass $k$ of $1 \mathrm{mmt}$, for each vessel or boat that operates for one hour, a crew of 10 fishermen can catch $1 \times 10^{-6} \mathrm{mmt}$ or 1 metric tonne of fish.

Finally, the financial-markets discount rate $\rho$ is $5 \%$ p.a. and the natural rate of stock collapse $\lambda$ (without a marine reserve) is 0.02 (i.e., every year the stock has a probability of 0.02 of collapsing). The reserve size $s$ is defined as the percentage of biomass not subject to exploitation. This is equivalent to $\mathrm{s}$ being the percentage of marine waters fenced off under the homogeneous stock distribution assumption. Any feasible or workable reserve size 
must be under $95 \%$ (1-c/pqk) and the calculated optimal reserve size $s^{*}$ (that maximizes the total expected stock value) is $41.94 \%$. This will achieve a seasonal harvest profit $\Pi^{s}$ of AUD\$20.88 million (out of a sustained harvest output $H^{s}$ of $0.002481 \mathrm{mmt}$ and utilizing harvesting effort $E^{s}$ of 78,702 worker-boat-hours each season). The superscripts * and $s$ imply the optimal and the sustainable, respectively. The maximum total expected stock value is $E\left(V^{S}\right)^{*}$ (the maximum $E\left(V^{S}\right)$ value) = AUD\$338.89 million. Following this harvesting program, an expected 33.377 harvest seasons $\left(t^{*}\right)$ will pass before $E\left(V^{\circ}\right) *$ is realized, with a probability of success, $\mathrm{P}\left(E\left(V^{\circ}\right)^{*}\right)$, of 0.679. The probabilities of achieving $50 \%$ and $75 \%$ of $E\left(V^{\wp}\right)^{*}$, i.e., $\mathrm{P}\left(0.5 E\left(V^{\wp}\right)^{*}\right)$ and $\mathrm{P}\left(0.75 E\left(V^{\wp}\right)^{*}\right)$, are 0.886 and 0.804 respectively. It is not possible to achieve $125 \%$ and $150 \%$ of $E\left(V^{\curvearrowright}\right)^{*}\left(\mathrm{P}\left(1.25 E\left(V^{\curvearrowright}\right)^{*}\right)=\mathrm{P}\left(1.5 E\left(V^{\curvearrowright}\right)^{*}\right)=0\right)$. Finally, the resulting sustained biomass $X_{2}^{s}$ is $0.543 \mathrm{mmt}$ (the lower sustained biomass $X_{1}^{s}=0.457 \mathrm{mmt}$ will not be pursued by managers).

Table 2. Comparative statics on maximum total expected fish stock value

\begin{tabular}{|c|c|c|c|c|c|c|c|c|}
\hline & Base scenario & Scenario 2 & Scenario 3 & Scenario 4 & Scenario 5 & Scenario 6 & Scenario 7 & Scenario 8 \\
\hline Management objectives: & Output values: & $\mathrm{p}=\$ 15 / \mathrm{kg}$ & $\mathrm{k}=2 \mathrm{mmt}$ & $\begin{array}{l}\mathrm{q}=3 \times 10^{-} \\
/ \mathrm{mbh} / \mathrm{mmt} \\
\text { biomass }\end{array}$ & $\mathrm{r}=5 \%$ p.a. & $\mathrm{c}=\$ 100 / \mathrm{mbh}$ & $\rho=10 \%$ p.a. & $\lambda=0.1$ \\
\hline $1-\mathrm{c} / \mathrm{pqk}$ & $95.00 \%$ & $96.67 \%$ & $97.50 \%$ & $98.33 \%$ & $95.00 \%$ & $90.00 \%$ & $95.00 \%$ & $95.00 \%$ \\
\hline s* & $41.94 \%$ & $53.87 \%$ & $60.70 \%$ & $68.52 \%$ & $41.94 \%$ & $12.72 \%$ & $21.39 \%$ & $68.92 \%$ \\
\hline$\Pi^{\mathrm{s}}$ & $\$ 20.879$ & $\$ 32.276$ & $\$ 43.842$ & $\$ 22.423$ & $\$ 104.397$ & $\$ 19.600$ & $\$ 21.921$ & $\$ 17.604$ \\
\hline $\mathrm{E}\left(\mathrm{V}^{\mathrm{s}}\right)^{*}$ & $\$ 338.887$ & $\$ 544.969$ & $\$ 757.708$ & $\$ 398.303$ & $\$ 1,694.436$ & $\$ 290.552$ & $\$ 189.427$ & $\$ 217.110$ \\
\hline $\mathrm{H}^{\mathrm{s}}$ & 0.002481 & 0.002487 & 0.004980 & 0.002493 & 0.012407 & 0.002467 & 0.002490 & 0.002435 \\
\hline $\mathrm{E}^{\mathrm{s}}$ & 78,702 & 100,557 & 119,123 & 50,147 & 393,512 & 50,721 & 59,561 & 134,977 \\
\hline $\mathrm{X}_{1}^{\mathrm{s}}$ & 0.457 & 0.464 & 0.936 & 0.474 & 0.457 & 0.443 & 0.468 & 0.420 \\
\hline $\mathrm{X}_{2}^{\mathrm{s}}$ & 0.543 & 0.536 & 1.064 & 0.526 & 0.543 & 0.557 & 0.532 & 0.580 \\
\hline $\mathrm{t}^{*}$ & 33.377 & 37.187 & 39.923 & 43.817 & 33.377 & 27.035 & 19.962 & 19.175 \\
\hline $\mathrm{P}\left(0.5 \mathrm{E}\left(\mathrm{V}^{\mathrm{s}}\right)^{*}\right)$ & 0.886 & 0.904 & 0.915 & 0.929 & 0.886 & 0.851 & 0.915 & 0.795 \\
\hline $\mathrm{P}\left(0.75 \mathrm{E}\left(\mathrm{V}^{\mathrm{s}}\right)^{*}\right)$ & 0.804 & 0.831 & 0.849 & 0.871 & 0.804 & 0.753 & 0.849 & 0.680 \\
\hline $\mathrm{P}\left(\mathrm{E}\left(\mathrm{V}^{\mathrm{s}}\right)^{*}\right)$ & 0.679 & 0.710 & 0.731 & 0.759 & 0.679 & 0.624 & 0.731 & 0.551 \\
\hline $\mathrm{P}\left(1.25 \mathrm{E}\left(\mathrm{V}^{\mathrm{s}}\right)^{*}\right)$ & $\mathrm{n} / \mathrm{a}$ & $\mathrm{n} / \mathrm{a}$ & $\mathrm{n} / \mathrm{a}$ & $\mathrm{n} / \mathrm{a}$ & $\mathrm{n} / \mathrm{a}$ & 0.402 & $\mathrm{n} / \mathrm{a}$ & 0.400 \\
\hline $\mathrm{P}\left(1.5 \mathrm{E}\left(\mathrm{V}^{\mathrm{s}}\right)^{*}\right)$ & $\mathrm{n} / \mathrm{a}$ & $\mathrm{n} / \mathrm{a}$ & $\mathrm{n} / \mathrm{a}$ & $\mathrm{n} / \mathrm{a}$ & $\mathrm{n} / \mathrm{a}$ & $\mathrm{n} / \mathrm{a}$ & $\mathrm{n} / \mathrm{a}$ & 0.200 \\
\hline
\end{tabular}

In scenario 2, $p$ is raised to AUD $\$ 15$ per $\mathrm{kg}$ (keeping all other input parameters unchanged). The harvesting fleet still aims to maximize periodic harvest profit and total expected stock value by trading off this maximum periodic profit with the risk of sudden stock collapse. Compared to the base scenario, $s^{*}$ is increased to $53.87 \%$ but still within the feasible limit of $96.67 \%$. This will achieve a higher $\Pi^{s}$ of AUD $\$ 32.28$ million (out of a higher $H^{s}$ of $0.002487 \mathrm{mmt}$ and utilizing higher $E^{s}$ of 100,557 worker-boat-hours each season). $E\left(V^{s}\right) *$ is higher as AUD $\$ 544.97$ million. In this scenario, more seasons $\left(t^{*}=37.19\right)$ are required to achieve $E\left(V^{\S}\right)^{*}$ but the probability of success is also higher $(0.710)$. The probabilities of achieving $50 \%$ and $75 \%$ of $E\left(V^{s}\right) *$ are also higher at 0.904 and 0.831 respectively, compared to those in the based scenario. However, $X_{2}^{s}$ is lower at 0.536 $\mathrm{mmt}$ despite (or indeed because of) the more alluring market price. Again it is impossible to achieve $125 \%$ or $150 \%$ of $E\left(V^{\varsigma}\right)$.

In scenario $3, k$ is raised to $2 \mathrm{mmt} . s^{*}$ is increased to $60.70 \%$ but within the new feasibility limit of $97.50 \%$. This will achieve a higher $\Pi^{s}$ of AUD $\$ 43.84$ million (out of a higher $H^{s}$ of $0.00498 \mathrm{mmt}$ and utilizing higher $E^{s}$ of 119,123 worker-boat-hours each season). $E\left(V^{\S}\right) *$ is higher at AUD $\$ 757.71$ million. Still more seasons $\left(t^{*}=39.92\right)$ are required to achieve $E\left(V^{s}\right)^{*}$ but the probability of success is also increased to 0.731 . The probabilities of achieving $50 \%$ and $75 \%$ of $E\left(V^{\diamond}\right)^{*}$ are also correspondingly higher at 0.915 and 0.849 respectively. With a higher 
biomass $k$ to start with, the resulting sustainable stock size of $X_{2}^{s}$ is also higher at $1.0636 \mathrm{mmt}$.

In scenario $4, q$ is raised to $3 \times 10^{-7}$. All other input parameters remain unchanged from the base scenario, to which all comparisons are again made. $s^{*}$ is increased to $68.52 \%$ and is within the now more tolerable feasibility limit of $98.33 \%$. This will achieve a higher $\Pi^{s}$ of AUD $\$ 22.42$ million (out of a higher $H^{s}$ of $0.00249 \mathrm{mmt}$ and utilizing lower $E^{s}$ of 50,147.31 worker-boat-hours each season). Again, $E\left(V^{\diamond}\right)^{*}$ is higher at AUD $\$ 398.30$ million. The probability of success at achieving $E\left(V^{\circ}\right)^{*}$ is higher at 0.759 . On the other hand, more seasons $\left(t^{*}=43.82\right)$ are also required to achieve this. Correspondingly, the probabilities of successfully achieving $50 \%$ and $75 \%$ of $E\left(V^{\circ}\right)^{*}$ are higher at 0.929 and 0.871 respectively. With a higher catch efficiency, the sustainably harvested stock size of $X_{2}^{s}$ is not surprisingly lower at $0.526 \mathrm{mmt}$.

In the $5^{\text {th }}$ scenario, the stock growth rate $r$ is increased to $5 \%$. The optimal reserve size $s^{*}$ stays at $41.94 \%$ and within the same feasibility limit of $95 \%$. This will achieve a significantly higher seasonal harvest profit $\Pi^{s}$ of AUD $\$ 104.40$ million (out of a much higher $H^{s}$ of $0.01241 \mathrm{mmt}$ and utilizing an equally impressive higher $E^{s}$ of $393,511.52$ worker-boat-hours each season). The total expected stock value $E\left(V^{\infty}\right)^{*}$ has increased to AUD \$1,694.44 million. This suggests that a higher stock growth rate brings in substantially more economic benefits than a rise in market price, biomass or catch efficiency. What's more, all relevant probabilities of success, number of seasons required and the sustainably harvested stock size are steady.

In the $6^{\text {th }}$ scenario, $c$ is more costly at AUD $\$ 100$ per worker per boat per hour. $s^{*}$ is dramatically lowered to $12.72 \%$ but still within the now lower feasibility limit of $90 \% . \Pi^{s}, H^{s}, E^{s}, E\left(V^{s}\right)^{*}$ also dropped significantly to AUD $\$ 19.60$ million, $0.002467 \mathrm{mmt}$, 50,721.21 worker-boat-hours, and AUD\$290.55 million respectively. This suggests a higher harvesting cost (perhaps due to shortage of skilled fishermen, higher wages and/or expensive capital equipment) could be devastating to the fishing community. The probabilities of successfully achieving $E\left(V^{\diamond}\right) *$ or $50 \%, 75 \%$ or $125 \%$ of it are also lower to $0.624,0.851,0.753$ and 0.402 respectively. The only bright spot is that fewer seasons $\left(t^{*}=27.04\right)$ are required to achieve $E\left(V^{s}\right)^{*}$ and the sustained stock size $X_{2}^{s}$ is higher at $0.557 \mathrm{mmt}$.

In the $7^{\text {th }}$ scenario, $\rho$ is raised to $10 \%$ p.a. (perhaps during a recession). The effect of raising interest rate (or discount rate) is to slow down the economy, reducing investment, employment and consumption. The reason for the economy slowing down is that future earnings are discounted more (meaning less valuable compared to current earnings). Current borrowing costs are also higher and these ultimately reduce economic activity, including fishery. To make up for the lower future harvest profits, the stock is harvested more intensively. This leads to a lower optimal reserve size $s^{*}$ at $21.39 \%$ (within the same feasible boundary of $95 \%$ ). As a result of the more intensive use of the resource, $\Pi^{s}$ and $H^{s}$ are higher at AUD $\$ 21.92$ million and $0.00249 \mathrm{mmt}$ respectively. However, harvest effort $E^{s}$ is lower at 59,561.42 worker-boat-hours each season, reflecting a slowing economy. High interest rates eat into the total expected stock value $E\left(V^{\wp}\right)^{*}$, which dropped to AUD $\$ 189.43$ million. The lower $E\left(V^{\wp}\right)^{*}$ requires fewer seasons $\left(t^{*}=19.96\right)$ to achieve. The probabilities of success at achieving $50 \%, 75 \%$ and $100 \%$ of $E\left(V^{\beta}\right)^{*}$ are respectively higher at $0.915,0.849$ and 0.731 . Not surprisingly, the more intensive use of the stock lowered the sustainably harvested stock size $X_{2}^{s}$ to $0.532 \mathrm{mmt}$.

In the last scenario $8, \lambda$ is raised to 0.1 . This means catastrophic stock collapse (making all future harvests non-profitable) is now five times more likely than the base scenario. It is not surprising that a marine reserve is now more appealing as an insurance against stock collapse and $s^{*}$ is increased to $68.92 \%$ (within the same feasibility limit of 95\%). A higher reserve size eats into the harvest profit $\Pi^{s}$ and output $H^{s}$, which are both lower at AUD\$17.60 million and $0.00244 \mathrm{mmt}$ respectively. As a result, fishermen need to work harder at a higher $E^{s}$ of $134,976.96$ worker-boat-hours each season. The result is a lower $E\left(V^{\circ}\right)^{*}$ of AUD $\$ 217.11$ million. They now require only $t^{*}=19.18$ seasons to achieve but with a lower probability of success at 0.551 . The probabilities of 
success at achieving $50 \%, 75 \%, 125 \%$ and $150 \%$ of $E\left(V^{\varsigma}\right) *$ are all lower at $0.795,0.680,0.440$ and 0.200 respectively. The latter two are only possible (probability $>0$ ) with a lower $E\left(V^{s}\right)$ to begin with. Stronger protection measure (higher $s^{*}$ ) means that $X_{2}^{s}$ is also now higher at $0.580 \mathrm{mmt}$, vis-à-vis the base scenario.

\subsection{Simulating Competing Management Objectives}

In the next set of simulations, the previous eight scenarios are retained. However, I do not maximize the total expected stock value by selecting the optimal marine reserve size and harvest effort. Instead, I simulate the output values of competing management objectives by running the reserve size over its entire feasible range in each scenario (Tables 3 to 10). Unlike the reserve size, harvest effort cannot be manipulated in this manner. This is because fishers always fully exploit the regulatory environment. Therefore any less-than-optimal harvest effort will not be realistic.

Table 3. Simulating competing management objectives for base scenario

\begin{tabular}{|c|c|c|c|c|c|c|c|c|c|c|c|}
\hline $\begin{array}{l}\text { Management } \\
\text { objectives/ } \\
\text { Reserve size }\end{array}$ & $0.00 \%$ & $10.00 \%$ & $20.00 \%$ & $30.00 \%$ & $40.00 \%$ & $50.00 \%$ & $60.00 \%$ & $70.00 \%$ & $80.00 \%$ & $90.00 \%$ & $95.00 \%$ \\
\hline$\Pi^{\mathrm{s}}$ & $\$ 22.563$ & $\$ 22.299$ & $\$ 21.973$ & $\$ 21.556$ & $\$ 21.007$ & $\$ 20.250$ & $\$ 19.141$ & $\$ 17.361$ & $\$ 14.063$ & $\$ 6.250$ & $\$ 0.000$ \\
\hline$E\left(V^{s}\right)^{*}$ & $\$ 322.321$ & $\$ 327.932$ & $\$ 332.919$ & $\$ 336.814$ & $\$ 338.822$ & $\$ 337.500$ & $\$ 330.011$ & $\$ 310.020$ & $\$ 260.417$ & $\$ 120.192$ & $\$ 0.000$ \\
\hline $\mathrm{H}^{\mathrm{s}}$ & 0.002494 & 0.002492 & 0.002490 & 0.002487 & 0.002483 & 0.002475 & 0.002461 & 0.002431 & 0.002344 & 0.001875 & 0.000000 \\
\hline$E^{s}$ & 47,500 & 52,469 & 58,594 & 66,327 & 76,389 & 90,000 & 109,375 & 138,889 & 187,500 & 250,000 & 0 \\
\hline $\mathrm{X}_{1}^{\mathrm{s}}$ & 0.475 & 0.472 & 0.469 & 0.464 & 0.458 & 0.450 & 0.438 & 0.417 & 0.375 & 0.250 & 0.000 \\
\hline $\mathrm{X}_{2}^{\mathrm{s}}$ & 0.525 & 0.528 & 0.531 & 0.536 & 0.542 & 0.550 & 0.563 & 0.583 & 0.625 & 0.750 & 1.000 \\
\hline $\mathrm{t}$ & 25.055 & 26.583 & 28.341 & 30.397 & 32.845 & 35.835 & 39.620 & 44.672 & 52.054 & 65.162 & 78.637 \\
\hline $\mathrm{P}(\mathrm{t})$ & 0.606 & 0.620 & 0.635 & 0.653 & 0.674 & 0.699 & 0.728 & 0.765 & 0.812 & 0.878 & 0.924 \\
\hline $\mathrm{P}\left(0.5 \mathrm{E}\left(\mathrm{V}^{\mathrm{s}}\right)^{*}\right)$ & 0.828 & 0.842 & 0.856 & 0.870 & 0.883 & 0.897 & 0.911 & 0.923 & 0.929 & $\mathrm{n} / \mathrm{a}$ & $\mathrm{n} / \mathrm{a}$ \\
\hline $\mathrm{P}\left(0.75 \mathrm{E}\left(\mathrm{V}^{\mathrm{s}}\right)^{*}\right)$ & 0.718 & 0.738 & 0.759 & 0.779 & 0.800 & 0.821 & 0.840 & 0.854 & 0.829 & $\mathrm{n} / \mathrm{a}$ & $\mathrm{n} / \mathrm{a}$ \\
\hline $\mathrm{P}\left(\mathrm{E}\left(\mathrm{V}^{\mathrm{s}}\right)^{*}\right)$ & 0.573 & 0.598 & 0.624 & 0.649 & 0.674 & 0.696 & 0.707 & 0.639 & $\mathrm{n} / \mathrm{a}$ & $\mathrm{n} / \mathrm{a}$ & $\mathrm{n} / \mathrm{a}$ \\
\hline $\mathrm{P}\left(1.25 \mathrm{E}\left(\mathrm{V}^{\mathrm{s}}\right)^{*}\right)$ & 0.327 & 0.341 & 0.345 & 0.322 & $\mathrm{n} / \mathrm{a}$ & $\mathrm{n} / \mathrm{a}$ & $\mathrm{n} / \mathrm{a}$ & $\mathrm{n} / \mathrm{a}$ & $\mathrm{n} / \mathrm{a}$ & $\mathrm{n} / \mathrm{a}$ & $\mathrm{n} / \mathrm{a}$ \\
\hline $\mathrm{P}\left(1.5 \mathrm{E}\left(\mathrm{V}^{\mathrm{s}}\right)^{*}\right)$ & $\mathrm{n} / \mathrm{a}$ & $\mathrm{n} / \mathrm{a}$ & $\mathrm{n} / \mathrm{a}$ & $\mathrm{n} / \mathrm{a}$ & $\mathrm{n} / \mathrm{a}$ & $\mathrm{n} / \mathrm{a}$ & $\mathrm{n} / \mathrm{a}$ & $\mathrm{n} / \mathrm{a}$ & $\mathrm{n} / \mathrm{a}$ & $\mathrm{n} / \mathrm{a}$ & $\mathrm{n} / \mathrm{a}$ \\
\hline
\end{tabular}

Table 4. Simulating competing management objectives for scenario 2

\begin{tabular}{|c|c|c|c|c|c|c|c|c|c|c|c|}
\hline $\begin{array}{l}\text { Management } \\
\text { objectives/ } \\
\text { Reserve size }\end{array}$ & $0.00 \%$ & $10.00 \%$ & $20.00 \%$ & $30.00 \%$ & $40.00 \%$ & $50.00 \%$ & $60.00 \%$ & $70.00 \%$ & $80.00 \%$ & $90.00 \%$ & $96.67 \%$ \\
\hline$\Pi^{s}$ & $\$ 35.042$ & $\$ 34.774$ & $\$ 34.440$ & $\$ 34.014$ & $\$ 33.449$ & $\$ 32.667$ & $\$ 31.510$ & $\$ 29.630$ & $\$ 26.042$ & $\$ 16.667$ & $\$ 0.000$ \\
\hline $\mathrm{E}\left(\mathrm{V}^{\mathrm{s}}\right)^{*}$ & $\$ 500.595$ & $\$ 511.377$ & $\$ 521.820$ & $\$ 531.463$ & $\$ 539.501$ & $\$ 544.444$ & $\$ 543.283$ & $\$ 529.101$ & $\$ 482.253$ & $\$ 320.513$ & $\$ 0.000$ \\
\hline $\mathrm{H}^{\mathrm{s}}$ & 0.002497 & 0.002497 & 0.002496 & 0.002494 & 0.002492 & 0.002489 & 0.002483 & 0.002469 & 0.002431 & 0.002222 & 0.000000 \\
\hline$E^{s}$ & 48,333 & 53,498 & 59,896 & 68,027 & 78,704 & 93,333 & 114,583 & 148,148 & 208,333 & 333,333 & $(0)$ \\
\hline $\mathrm{X}_{1}^{\mathrm{s}}$ & 0.483 & 0.481 & 0.479 & 0.476 & 0.472 & 0.467 & 0.458 & 0.444 & 0.417 & 0.333 & $(0.000)$ \\
\hline $\mathrm{X}_{2}^{\mathrm{s}}$ & 0.517 & 0.519 & 0.521 & 0.524 & 0.528 & 0.533 & 0.542 & 0.556 & 0.583 & 0.667 & 1.000 \\
\hline $\mathrm{T}$ & 25.055 & 26.583 & 28.341 & 30.397 & 32.845 & 35.835 & 39.620 & 44.672 & 52.054 & 65.162 & 86.615 \\
\hline $\mathrm{P}(\mathrm{t})$ & 0.606 & 0.620 & 0.635 & 0.653 & 0.674 & 0.699 & 0.728 & 0.765 & 0.812 & 0.878 & 0.944 \\
\hline $\mathrm{P}\left(0.5 \mathrm{E}\left(\mathrm{V}^{\mathrm{s}}\right)^{*}\right)$ & 0.821 & 0.836 & 0.851 & 0.867 & 0.882 & 0.898 & 0.913 & 0.929 & 0.942 & 0.934 & $\mathrm{n} / \mathrm{a}$ \\
\hline $\mathrm{P}\left(0.75 \mathrm{E}\left(\mathrm{V}^{\mathrm{s}}\right)^{*}\right)$ & 0.705 & 0.727 & 0.750 & 0.773 & 0.797 & 0.822 & 0.846 & 0.869 & 0.884 & $\mathrm{n} / \mathrm{a}$ & $\mathrm{n} / \mathrm{a}$ \\
\hline $\mathrm{P}\left(\mathrm{E}\left(\mathrm{V}^{\mathrm{s}}\right)^{*}\right)$ & 0.548 & 0.576 & 0.606 & 0.636 & 0.667 & 0.698 & 0.726 & 0.739 & $\mathrm{n} / \mathrm{a}$ & $\mathrm{n} / \mathrm{a}$ & $\mathrm{n} / \mathrm{a}$ \\
\hline $\mathrm{P}\left(1.25 \mathrm{E}\left(\mathrm{V}^{\mathrm{s}}\right)^{*}\right)$ & 0.239 & 0.247 & 0.236 & $\mathrm{n} / \mathrm{a}$ & $\mathrm{n} / \mathrm{a}$ & $\mathrm{n} / \mathrm{a}$ & $\mathrm{n} / \mathrm{a}$ & $\mathrm{n} / \mathrm{a}$ & $\mathrm{n} / \mathrm{a}$ & $\mathrm{n} / \mathrm{a}$ & $\mathrm{n} / \mathrm{a}$ \\
\hline $\mathrm{P}\left(1.5 \mathrm{E}\left(\mathrm{V}^{\mathrm{s}}\right)^{*}\right)$ & $\mathrm{n} / \mathrm{a}$ & $\mathrm{n} / \mathrm{a}$ & $\mathrm{n} / \mathrm{a}$ & $\mathrm{n} / \mathrm{a}$ & $\mathrm{n} / \mathrm{a}$ & $\mathrm{n} / \mathrm{a}$ & $\mathrm{n} / \mathrm{a}$ & $\mathrm{n} / \mathrm{a}$ & $\mathrm{n} / \mathrm{a}$ & $\mathrm{n} / \mathrm{a}$ & $\mathrm{n} / \mathrm{a}$ \\
\hline
\end{tabular}


Table 5. Simulating competing management objectives for scenario 3

\begin{tabular}{|c|c|c|c|c|c|c|c|c|c|c|c|}
\hline $\begin{array}{l}\text { Management } \\
\text { objectives/ } \\
\text { Reserve size }\end{array}$ & $0.00 \%$ & $10.00 \%$ & $20.00 \%$ & $30.00 \%$ & $40.00 \%$ & $50.00 \%$ & $60.00 \%$ & $70.00 \%$ & $80.00 \%$ & $90.00 \%$ & $97.50 \%$ \\
\hline$\Pi^{\mathrm{s}}$ & $\$ 47.531$ & $\$ 47.261$ & $\$ 46.924$ & $\$ 46.492$ & $\$ 45.920$ & $\$ 45.125$ & $\$ 43.945$ & $\$ 42.014$ & $\$ 38.281$ & $\$ 28.125$ & $\$ 0.000$ \\
\hline $\mathrm{E}\left(\mathrm{V}^{\mathrm{s}}\right)^{*}$ & $\$ 679.018$ & $\$ 695.012$ & $\$ 710.967$ & $\$ 726.443$ & $\$ 740.647$ & $\$ 752.083$ & $\$ 757.678$ & $\$ 750.248$ & $\$ 708.912$ & $\$ 540.865$ & $\$ 0.000$ \\
\hline $\mathrm{H}^{\mathrm{s}}$ & 0.004997 & 0.004996 & 0.004995 & 0.004994 & 0.004991 & 0.004988 & 0.004980 & 0.004965 & 0.004922 & 0.004688 & 0.000000 \\
\hline$E^{s}$ & 48,750 & 54,012 & 60,547 & 68,878 & 79,861 & 95,000 & 117,188 & 152,778 & 218,750 & 375,000 & 0 \\
\hline $\mathrm{X}_{1}^{\mathrm{s}}$ & 0.975 & 0.972 & 0.969 & 0.964 & 0.958 & 0.950 & 0.938 & 0.917 & 0.875 & 0.750 & 0.000 \\
\hline $\mathrm{X}_{2}{ }^{\mathrm{s}}$ & 1.025 & 1.028 & 1.031 & 1.036 & 1.042 & 1.050 & 1.063 & 1.083 & 1.125 & 1.250 & 2.000 \\
\hline $\mathrm{T}$ & 25.055 & 26.583 & 28.341 & 30.397 & 32.845 & 35.835 & 39.620 & 44.672 & 52.054 & 65.162 & 92.302 \\
\hline$P(t)$ & 0.606 & 0.620 & 0.635 & 0.653 & 0.674 & 0.699 & 0.728 & 0.765 & 0.812 & 0.878 & 0.955 \\
\hline $\mathrm{P}\left(0.5 \mathrm{E}\left(\mathrm{V}^{\mathrm{s}}\right)^{*}\right)$ & 0.816 & 0.832 & 0.848 & 0.864 & 0.880 & 0.897 & 0.914 & 0.931 & 0.947 & 0.956 & $\mathrm{n} / \mathrm{a}$ \\
\hline $\mathrm{P}\left(0.75 \mathrm{E}\left(\mathrm{V}^{\mathrm{s}}\right)^{*}\right)$ & 0.695 & 0.718 & 0.743 & 0.768 & 0.793 & 0.820 & 0.847 & 0.873 & 0.897 & $\mathrm{n} / \mathrm{a}$ & $\mathrm{n} / \mathrm{a}$ \\
\hline $\mathrm{P}\left(\mathrm{E}\left(\mathrm{V}^{\mathrm{s}}\right)^{*}\right)$ & 0.528 & 0.559 & 0.590 & 0.624 & 0.658 & 0.694 & 0.728 & 0.757 & 0.694 & $\mathrm{n} / \mathrm{a}$ & $\mathrm{n} / \mathrm{a}$ \\
\hline $\mathrm{P}\left(1.25 \mathrm{E}\left(\mathrm{V}^{\mathrm{s}}\right)^{*}\right)$ & 0.106 & $\mathrm{n} / \mathrm{a}$ & $\mathrm{n} / \mathrm{a}$ & $\mathrm{n} / \mathrm{a}$ & $\mathrm{n} / \mathrm{a}$ & $\mathrm{n} / \mathrm{a}$ & $\mathrm{n} / \mathrm{a}$ & $\mathrm{n} / \mathrm{a}$ & $\mathrm{n} / \mathrm{a}$ & $\mathrm{n} / \mathrm{a}$ & $\mathrm{n} / \mathrm{a}$ \\
\hline $\mathrm{P}\left(1.5 \mathrm{E}\left(\mathrm{V}^{\mathrm{s}}\right)^{*}\right)$ & $\mathrm{n} / \mathrm{a}$ & $\mathrm{n} / \mathrm{a}$ & $\mathrm{n} / \mathrm{a}$ & $\mathrm{n} / \mathrm{a}$ & $\mathrm{n} / \mathrm{a}$ & $\mathrm{n} / \mathrm{a}$ & $\mathrm{n} / \mathrm{a}$ & $\mathrm{n} / \mathrm{a}$ & $\mathrm{n} / \mathrm{a}$ & $\mathrm{n} / \mathrm{a}$ & $\mathrm{n} / \mathrm{a}$ \\
\hline
\end{tabular}

Table 6. Simulating competing management objectives for scenario 4

\begin{tabular}{|c|c|c|c|c|c|c|c|c|c|c|c|}
\hline $\begin{array}{l}\text { Management } \\
\text { objectives/ } \\
\text { Reserve size }\end{array}$ & $0.00 \%$ & $10.00 \%$ & $20.00 \%$ & $30.00 \%$ & $40.00 \%$ & $50.00 \%$ & $60.00 \%$ & $70.00 \%$ & $80.00 \%$ & $90.00 \%$ & $98.33 \%$ \\
\hline$\Pi^{\mathrm{s}}$ & $\$ 24.174$ & $\$ 24.083$ & $\$ 23.969$ & $\$ 23.824$ & $\$ 23.630$ & $\$ 23.361$ & $\$ 22.960$ & $\$ 22.299$ & $\$ 21.007$ & $\$ 17.361$ & $\$ 0.000$ \\
\hline $\mathrm{E}\left(\mathrm{V}^{\mathrm{s}}\right)^{*}$ & $\$ 345.337$ & $\$ 354.157$ & $\$ 363.169$ & $\$ 372.245$ & $\$ 381.136$ & $\$ 389.352$ & $\$ 395.863$ & $\$ 398.203$ & $\$ 389.017$ & $\$ 333.868$ & $\$ 0.000$ \\
\hline $\mathrm{H}^{\mathrm{s}}$ & 0.002499 & 0.002499 & 0.002499 & 0.002499 & 0.002498 & 0.002497 & 0.002496 & 0.002492 & 0.002483 & 0.002431 & 0.000000 \\
\hline$E^{s}$ & 16,389 & 18,176 & 20,399 & 23,243 & 27,006 & 32,222 & 39,931 & 52,469 & 76,389 & 138,889 & 0 \\
\hline $\mathrm{X}_{1}^{\mathrm{s}}$ & 0.492 & 0.491 & 0.490 & 0.488 & 0.486 & 0.483 & 0.479 & 0.472 & 0.458 & 0.417 & 0.000 \\
\hline $\mathrm{X}_{2}^{\mathrm{s}}$ & 0.508 & 0.509 & 0.510 & 0.512 & 0.514 & 0.517 & 0.521 & 0.528 & 0.542 & 0.583 & 1.000 \\
\hline $\mathrm{t}$ & 25.055 & 26.583 & 28.341 & 30.397 & 32.845 & 35.835 & 39.620 & 44.672 & 52.054 & 65.162 & 100.346 \\
\hline $\mathrm{P}(\mathrm{t})$ & 0.606 & 0.620 & 0.635 & 0.653 & 0.674 & 0.699 & 0.728 & 0.765 & 0.812 & 0.878 & 0.967 \\
\hline $\mathrm{P}\left(0.5 \mathrm{E}\left(\mathrm{V}^{\mathrm{s}}\right)^{*}\right)$ & 0.809 & 0.825 & 0.842 & 0.859 & 0.877 & 0.895 & 0.913 & 0.931 & 0.950 & 0.966 & $\mathrm{n} / \mathrm{a}$ \\
\hline $\mathrm{P}\left(0.75 \mathrm{E}\left(\mathrm{V}^{\mathrm{s}}\right)^{*}\right)$ & 0.681 & 0.706 & 0.732 & 0.759 & 0.787 & 0.815 & 0.845 & 0.875 & 0.905 & 0.924 & $\mathrm{n} / \mathrm{a}$ \\
\hline $\mathrm{P}\left(\mathrm{E}\left(\mathrm{V}^{\mathrm{s}}\right)^{*}\right)$ & 0.499 & 0.532 & 0.566 & 0.603 & 0.641 & 0.682 & 0.724 & 0.765 & 0.789 & $\mathrm{n} / \mathrm{a}$ & $\mathrm{n} / \mathrm{a}$ \\
\hline $\mathrm{P}\left(1.25 \mathrm{E}\left(\mathrm{V}^{\mathrm{s}}\right)^{*}\right)$ & $\mathrm{n} / \mathrm{a}$ & $\mathrm{n} / \mathrm{a}$ & $\mathrm{n} / \mathrm{a}$ & $\mathrm{n} / \mathrm{a}$ & $\mathrm{n} / \mathrm{a}$ & $\mathrm{n} / \mathrm{a}$ & $\mathrm{n} / \mathrm{a}$ & $\mathrm{n} / \mathrm{a}$ & $\mathrm{n} / \mathrm{a}$ & $\mathrm{n} / \mathrm{a}$ & $\mathrm{n} / \mathrm{a}$ \\
\hline $\mathrm{P}\left(1.5 \mathrm{E}\left(\mathrm{V}^{\mathrm{s}}\right)^{*}\right)$ & $\mathrm{n} / \mathrm{a}$ & $\mathrm{n} / \mathrm{a}$ & $\mathrm{n} / \mathrm{a}$ & $\mathrm{n} / \mathrm{a}$ & $\mathrm{n} / \mathrm{a}$ & $\mathrm{n} / \mathrm{a}$ & $\mathrm{n} / \mathrm{a}$ & $\mathrm{n} / \mathrm{a}$ & $\mathrm{n} / \mathrm{a}$ & $\mathrm{n} / \mathrm{a}$ & $\mathrm{n} / \mathrm{a}$ \\
\hline
\end{tabular}

Table 7. Simulating competing management objectives for scenario 5

\begin{tabular}{|c|c|c|c|c|c|c|c|c|c|c|c|}
\hline $\begin{array}{l}\text { Management } \\
\text { objectives/ } \\
\text { Reserve size }\end{array}$ & $0.00 \%$ & $10.00 \%$ & $20.00 \%$ & $30.00 \%$ & $40.00 \%$ & $50.00 \%$ & $60.00 \%$ & $70.00 \%$ & $80.00 \%$ & $90.00 \%$ & $95.00 \%$ \\
\hline$\Pi^{\mathrm{s}}$ & $\$ 112.813$ & $\$ 111.497$ & $\$ 109.863$ & $\$ 107.781$ & $\$ 105.035$ & $\$ 101.250$ & $\$ 95.703$ & $\$ 86.806$ & $\$ 70.313$ & $\$ 31.250$ & $\$ 0.000$ \\
\hline $\mathrm{E}\left(\mathrm{V}^{\mathrm{s}}\right)^{*}$ & $\$ 1,611.607$ & $\$ 1,639.660$ & $\$ 1,664.595$ & $\$ 1,684.072$ & $\$ 1,694.108$ & $\$ 1,687.500$ & $\$ 1,650.054$ & $\$ 1,550.099$ & $\$ 1,302.083$ & $\$ 600.962$ & $\$ 0.000$ \\
\hline $\mathrm{H}^{\mathrm{s}}$ & 0.012469 & 0.012461 & 0.012451 & 0.012436 & 0.012413 & 0.012375 & 0.012305 & 0.012153 & 0.011719 & 0.009375 & 0.000000 \\
\hline$E^{s}$ & 237,500 & 262,346 & 292,969 & 331,633 & 381,944 & 450,000 & 546,875 & 694,444 & 937,500 & $1,250,000$ & 0 \\
\hline $\mathrm{X}_{1}^{\mathrm{s}}$ & 0.475 & 0.472 & 0.469 & 0.464 & 0.458 & 0.450 & 0.438 & 0.417 & 0.375 & 0.250 & 0.000 \\
\hline $\mathrm{X}_{2}^{\mathrm{s}}$ & 0.525 & 0.528 & 0.531 & 0.536 & 0.542 & 0.550 & 0.563 & 0.583 & 0.625 & 0.750 & 1.000 \\
\hline $\mathrm{t}$ & 25.055 & 26.583 & 28.341 & 30.397 & 32.845 & 35.835 & 39.620 & 44.672 & 52.054 & 65.162 & 78.637 \\
\hline $\mathrm{P}(\mathrm{t})$ & 0.606 & 0.620 & 0.635 & 0.653 & 0.674 & 0.699 & 0.728 & 0.765 & 0.812 & 0.878 & 0.924 \\
\hline $\mathrm{P}\left(0.5 \mathrm{E}\left(\mathrm{V}^{\mathrm{s}}\right)^{*}\right)$ & 0.828 & 0.842 & 0.856 & 0.870 & 0.883 & 0.897 & 0.911 & 0.923 & 0.929 & $\mathrm{n} / \mathrm{a}$ & $\mathrm{n} / \mathrm{a}$ \\
\hline $\mathrm{P}\left(0.75 \mathrm{E}\left(\mathrm{V}^{\mathrm{s}}\right)^{*}\right)$ & 0.718 & 0.738 & 0.759 & 0.779 & 0.800 & 0.821 & 0.840 & 0.854 & 0.829 & $\mathrm{n} / \mathrm{a}$ & $\mathrm{n} / \mathrm{a}$ \\
\hline $\mathrm{P}\left(\mathrm{E}\left(\mathrm{V}^{\mathrm{s}}\right)^{*}\right)$ & 0.573 & 0.598 & 0.624 & 0.649 & 0.674 & 0.696 & 0.707 & 0.639 & $\mathrm{n} / \mathrm{a}$ & $\mathrm{n} / \mathrm{a}$ & $\mathrm{n} / \mathrm{a}$ \\
\hline $\mathrm{P}\left(1.25 \mathrm{E}\left(\mathrm{V}^{\mathrm{s}}\right)^{*}\right)$ & 0.327 & 0.341 & 0.345 & 0.322 & $\mathrm{n} / \mathrm{a}$ & $\mathrm{n} / \mathrm{a}$ & $\mathrm{n} / \mathrm{a}$ & $\mathrm{n} / \mathrm{a}$ & $\mathrm{n} / \mathrm{a}$ & $\mathrm{n} / \mathrm{a}$ & $\mathrm{n} / \mathrm{a}$ \\
\hline $\mathrm{P}\left(1.5 \mathrm{E}\left(\mathrm{V}^{\mathrm{s}}\right)^{*}\right)$ & $\mathrm{n} / \mathrm{a}$ & $\mathrm{n} / \mathrm{a}$ & $\mathrm{n} / \mathrm{a}$ & $\mathrm{n} / \mathrm{a}$ & $\mathrm{n} / \mathrm{a}$ & $\mathrm{n} / \mathrm{a}$ & $\mathrm{n} / \mathrm{a}$ & $\mathrm{n} / \mathrm{a}$ & $\mathrm{n} / \mathrm{a}$ & $\mathrm{n} / \mathrm{a}$ & $\mathrm{n} / \mathrm{a}$ \\
\hline
\end{tabular}


Table 8. Simulating competing management objectives for scenario 6

\begin{tabular}{|c|c|c|c|c|c|c|c|c|c|c|}
\hline $\begin{array}{l}\text { Management } \\
\text { objectives/ } \\
\text { Reserve size }\end{array}$ & $0.00 \%$ & $10.00 \%$ & $20.00 \%$ & $30.00 \%$ & $40.00 \%$ & $50.00 \%$ & $60.00 \%$ & $70.00 \%$ & $80.00 \%$ & $90.00 \%$ \\
\hline$\Pi^{\mathrm{s}}$ & $\$ 20.250$ & $\$ 19.753$ & $\$ 19.141$ & $\$ 18.367$ & $\$ 17.361$ & $\$ 16.000$ & $\$ 14.063$ & $\$ 11.111$ & $\$ 6.250$ & $\$ 0.000$ \\
\hline $\mathrm{E}\left(\mathrm{V}^{\mathrm{s}}\right)^{*}$ & $\$ 289.286$ & $\$ 290.487$ & $\$ 290.009$ & $\$ 286.990$ & $\$ 280.018$ & $\$ 266.667$ & $\$ 242.457$ & $\$ 198.413$ & $\$ 115.741$ & $\$ 0.000$ \\
\hline $\mathrm{H}^{\mathrm{s}}$ & 0.002475 & 0.002469 & 0.002461 & 0.002449 & 0.002431 & 0.002400 & 0.002344 & 0.002222 & 0.001875 & 0.000000 \\
\hline$E^{s}$ & 45,000 & 49,383 & 54,688 & 61,224 & 69,444 & 80,000 & 93,750 & 111,111 & 125,000 & 0 \\
\hline $\mathrm{X}_{1}^{\mathrm{s}}$ & 0.450 & 0.444 & 0.438 & 0.429 & 0.417 & 0.400 & 0.375 & 0.333 & 0.250 & 0.000 \\
\hline $\mathrm{X}_{2}{ }^{\mathrm{s}}$ & 0.550 & 0.556 & 0.563 & 0.571 & 0.583 & 0.600 & 0.625 & 0.667 & 0.750 & 1.000 \\
\hline $\mathrm{t}$ & 25.055 & 26.583 & 28.341 & 30.397 & 32.845 & 35.835 & 39.620 & 44.672 & 52.054 & 65.162 \\
\hline $\mathrm{P}(\mathrm{t})$ & 0.606 & 0.620 & 0.635 & 0.653 & 0.674 & 0.699 & 0.728 & 0.765 & 0.812 & 0.878 \\
\hline $\mathrm{P}\left(0.5 \mathrm{E}\left(\mathrm{V}^{\mathrm{s}}\right)^{*}\right)$ & 0.837 & 0.848 & 0.858 & 0.869 & 0.878 & 0.886 & 0.890 & 0.880 & $\mathrm{n} / \mathrm{a}$ & $\mathrm{n} / \mathrm{a}$ \\
\hline $\mathrm{P}\left(0.75 \mathrm{E}\left(\mathrm{V}^{\mathrm{s}}\right)^{*}\right)$ & 0.734 & 0.749 & 0.764 & 0.777 & 0.789 & 0.796 & 0.788 & 0.623 & $\mathrm{n} / \mathrm{a}$ & $\mathrm{n} / \mathrm{a}$ \\
\hline $\mathrm{P}\left(\mathrm{E}\left(\mathrm{V}^{\mathrm{s}}\right)^{*}\right)$ & 0.603 & 0.620 & 0.634 & 0.645 & 0.647 & 0.621 & $\mathrm{n} / \mathrm{a}$ & $\mathrm{n} / \mathrm{a}$ & $\mathrm{n} / \mathrm{a}$ & $\mathrm{n} / \mathrm{a}$ \\
\hline $\mathrm{P}\left(1.25 \mathrm{E}\left(\mathrm{V}^{\mathrm{s}}\right)^{*}\right)$ & 0.403 & 0.404 & 0.386 & 0.285 & $\mathrm{n} / \mathrm{a}$ & $\mathrm{n} / \mathrm{a}$ & $\mathrm{n} / \mathrm{a}$ & $\mathrm{n} / \mathrm{a}$ & $\mathrm{n} / \mathrm{a}$ & $\mathrm{n} / \mathrm{a}$ \\
\hline $\mathrm{P}\left(1.5 \mathrm{E}\left(\mathrm{V}^{\mathrm{s}}\right)^{*}\right)$ & $\mathrm{n} / \mathrm{a}$ & $\mathrm{n} / \mathrm{a}$ & $\mathrm{n} / \mathrm{a}$ & $\mathrm{n} / \mathrm{a}$ & $\mathrm{n} / \mathrm{a}$ & $\mathrm{n} / \mathrm{a}$ & $\mathrm{n} / \mathrm{a}$ & $\mathrm{n} / \mathrm{a}$ & $\mathrm{n} / \mathrm{a}$ & $\mathrm{n} / \mathrm{a}$ \\
\hline
\end{tabular}

Table 9. Simulating competing management objectives for scenario 7

\begin{tabular}{|c|c|c|c|c|c|c|c|c|c|c|c|}
\hline $\begin{array}{l}\text { Management } \\
\text { objectives/ } \\
\text { Reserve size }\end{array}$ & $0.00 \%$ & $10.00 \%$ & $20.00 \%$ & $30.00 \%$ & $40.00 \%$ & $50.00 \%$ & $60.00 \%$ & $70.00 \%$ & $80.00 \%$ & $90.00 \%$ & $95.00 \%$ \\
\hline$\Pi^{\mathrm{s}}$ & $\$ 22.563$ & $\$ 22.299$ & $\$ 21.973$ & $\$ 21.556$ & $\$ 21.007$ & $\$ 20.250$ & $\$ 19.141$ & $\$ 17.361$ & $\$ 14.063$ & $\$ 6.250$ & $\$ 0.000$ \\
\hline $\mathrm{E}\left(\mathrm{V}^{\mathrm{s}}\right)^{*}$ & $\$ 188.021$ & $\$ 188.978$ & $\$ 189.419$ & $\$ 189.089$ & $\$ 187.562$ & $\$ 184.091$ & $\$ 177.228$ & $\$ 163.784$ & $\$ 135.216$ & $\$ 61.275$ & $\$ 0.000$ \\
\hline $\mathrm{H}^{\mathrm{s}}$ & 0.002494 & 0.002492 & 0.002490 & 0.002487 & 0.002483 & 0.002475 & 0.002461 & 0.002431 & 0.002344 & 0.001875 & 0.000000 \\
\hline$E^{s}$ & 47,500 & 52,469 & 58,594 & 66,327 & 76,389 & 90,000 & 109,375 & 138,889 & 187,500 & 250,000 & 0 \\
\hline $\mathrm{X}_{1}^{\mathrm{s}}$ & 0.475 & 0.472 & 0.469 & 0.464 & 0.458 & 0.450 & 0.438 & 0.417 & 0.375 & 0.250 & 0.000 \\
\hline $\mathrm{X}_{2}{ }^{\mathrm{s}}$ & 0.525 & 0.528 & 0.531 & 0.536 & 0.542 & 0.550 & 0.563 & 0.583 & 0.625 & 0.750 & 1.000 \\
\hline $\mathrm{t}$ & 17.918 & 18.803 & 19.810 & 20.971 & 22.336 & 23.979 & 26.027 & 28.717 & 32.581 & 39.318 & 46.151 \\
\hline $\mathrm{P}(\mathrm{t})$ & 0.699 & 0.713 & 0.728 & 0.746 & 0.765 & 0.787 & 0.812 & 0.842 & 0.878 & 0.924 & 0.955 \\
\hline $\mathrm{P}\left(0.5 \mathrm{E}\left(\mathrm{V}^{\mathrm{s}}\right)^{*}\right)$ & 0.897 & 0.905 & 0.914 & 0.922 & 0.931 & 0.939 & 0.947 & 0.954 & 0.956 & $\mathrm{n} / \mathrm{a}$ & $\mathrm{n} / \mathrm{a}$ \\
\hline $\mathrm{P}\left(0.75 \mathrm{E}\left(\mathrm{V}^{\mathrm{s}}\right)^{*}\right)$ & 0.820 & 0.833 & 0.847 & 0.860 & 0.873 & 0.886 & 0.897 & 0.903 & $\mathrm{n} / \mathrm{a}$ & $\mathrm{n} / \mathrm{a}$ & $\mathrm{n} / \mathrm{a}$ \\
\hline $\mathrm{P}\left(\mathrm{E}\left(\mathrm{V}^{\mathrm{s}}\right)^{*}\right)$ & 0.694 & 0.711 & 0.728 & 0.744 & 0.757 & 0.760 & 0.694 & $\mathrm{n} / \mathrm{a}$ & $\mathrm{n} / \mathrm{a}$ & $\mathrm{n} / \mathrm{a}$ & $\mathrm{n} / \mathrm{a}$ \\
\hline $\mathrm{P}\left(1.25 \mathrm{E}\left(\mathrm{V}^{\mathrm{s}}\right)^{*}\right)$ & $\mathrm{n} / \mathrm{a}$ & $\mathrm{n} / \mathrm{a}$ & $\mathrm{n} / \mathrm{a}$ & $\mathrm{n} / \mathrm{a}$ & $\mathrm{n} / \mathrm{a}$ & $\mathrm{n} / \mathrm{a}$ & $\mathrm{n} / \mathrm{a}$ & $\mathrm{n} / \mathrm{a}$ & $\mathrm{n} / \mathrm{a}$ & $\mathrm{n} / \mathrm{a}$ & $\mathrm{n} / \mathrm{a}$ \\
\hline $\mathrm{P}\left(1.5 \mathrm{E}\left(\mathrm{V}^{\mathrm{s}}\right)^{*}\right)$ & $\mathrm{n} / \mathrm{a}$ & $\mathrm{n} / \mathrm{a}$ & $\mathrm{n} / \mathrm{a}$ & $\mathrm{n} / \mathrm{a}$ & $\mathrm{n} / \mathrm{a}$ & $\mathrm{n} / \mathrm{a}$ & $\mathrm{n} / \mathrm{a}$ & $\mathrm{n} / \mathrm{a}$ & $\mathrm{n} / \mathrm{a}$ & $\mathrm{n} / \mathrm{a}$ & $\mathrm{n} / \mathrm{a}$ \\
\hline
\end{tabular}

Table 10. Simulating competing management objectives for scenario 8

\begin{tabular}{|c|c|c|c|c|c|c|c|c|c|c|c|}
\hline $\begin{array}{l}\text { Management } \\
\text { objectives/ } \\
\text { Reserve size }\end{array}$ & $0.00 \%$ & $10.00 \%$ & $20.00 \%$ & $30.00 \%$ & $40.00 \%$ & $50.00 \%$ & $60.00 \%$ & $70.00 \%$ & $80.00 \%$ & $90.00 \%$ & $95.00 \%$ \\
\hline$\Pi^{\mathrm{s}}$ & $\$ 22.563$ & $\$ 22.299$ & $\$ 21.973$ & $\$ 21.556$ & $\$ 21.007$ & $\$ 20.250$ & $\$ 19.141$ & $\$ 17.361$ & $\$ 14.063$ & $\$ 6.250$ & $\$ 0.000$ \\
\hline $\mathrm{E}\left(\mathrm{V}^{\mathrm{s}}\right)^{*}$ & $\$ 150.417$ & $\$ 159.281$ & $\$ 169.020$ & $\$ 179.634$ & $\$ 190.972$ & $\$ 202.500$ & $\$ 212.674$ & $\$ 217.014$ & $\$ 200.893$ & $\$ 104.167$ & $\$ 0.000$ \\
\hline $\mathrm{H}^{\mathrm{s}}$ & 0.002494 & 0.002492 & 0.002490 & 0.002487 & 0.002483 & 0.002475 & 0.002461 & 0.002431 & 0.002344 & 0.001875 & 0.000000 \\
\hline$E^{s}$ & 47,500 & 52,469 & 58,594 & 66,327 & 76,389 & 90,000 & 109,375 & 138,889 & 187,500 & 250,000 & 0 \\
\hline $\mathrm{X}_{1}^{\mathrm{s}}$ & 0.475 & 0.472 & 0.469 & 0.464 & 0.458 & 0.450 & 0.438 & 0.417 & 0.375 & 0.250 & 0.000 \\
\hline $\mathrm{X}_{2}^{\mathrm{s}}$ & 0.525 & 0.528 & 0.531 & 0.536 & 0.542 & 0.550 & 0.563 & 0.583 & 0.625 & 0.750 & 1.000 \\
\hline $\mathrm{t}$ & 8.109 & 8.837 & 9.710 & 10.780 & 12.123 & 13.863 & 16.219 & 19.617 & 25.055 & 35.835 & 47.958 \\
\hline$P(t)$ & 0.444 & 0.451 & 0.460 & 0.470 & 0.483 & 0.500 & 0.523 & 0.555 & 0.606 & 0.699 & 0.787 \\
\hline $\mathrm{P}\left(0.5 \mathrm{E}\left(\mathrm{V}^{\mathrm{s}}\right)^{*}\right)$ & 0.577 & 0.605 & 0.635 & 0.666 & 0.699 & 0.732 & 0.766 & 0.799 & 0.823 & 0.667 & $\mathrm{n} / \mathrm{a}$ \\
\hline $\mathrm{P}\left(0.75 \mathrm{E}\left(\mathrm{V}^{\mathrm{s}}\right)^{*}\right)$ & 0.409 & 0.441 & 0.477 & 0.515 & 0.555 & 0.598 & 0.642 & 0.684 & 0.708 & $\mathrm{n} / \mathrm{a}$ & $\mathrm{n} / \mathrm{a}$ \\
\hline $\mathrm{P}\left(\mathrm{E}\left(\mathrm{V}^{\mathrm{s}}\right)^{*}\right)$ & 0.269 & 0.301 & 0.336 & 0.375 & 0.418 & 0.464 & 0.512 & 0.555 & 0.554 & $\mathrm{n} / \mathrm{a}$ & $\mathrm{n} / \mathrm{a}$ \\
\hline $\mathrm{P}\left(1.25 \mathrm{E}\left(\mathrm{V}^{\mathrm{s}}\right)^{*}\right)$ & 0.159 & 0.185 & 0.215 & 0.249 & 0.288 & 0.330 & 0.373 & 0.401 & 0.262 & $\mathrm{n} / \mathrm{a}$ & $\mathrm{n} / \mathrm{a}$ \\
\hline $\mathrm{P}\left(1.5 \mathrm{E}\left(\mathrm{V}^{\mathrm{s}}\right)^{*}\right)$ & 0.077 & 0.095 & 0.115 & 0.139 & 0.167 & 0.196 & 0.218 & 0.189 & $\mathrm{n} / \mathrm{a}$ & $\mathrm{n} / \mathrm{a}$ & $\mathrm{n} / \mathrm{a}$ \\
\hline
\end{tabular}


The feasible limit (the last column of each table) for the reserve size is the largest acceptable percentage of the biomass (or surface area of the fishing ground if the stock is sufficiently mobile) beyond which seasonal harvest output, effort and profit will become negative. In all eight scenarios, the smaller the reserve size $s$ (going from right to left along the tables), the higher the seasonal profit $\Pi^{s}$ and seasonal output $H^{s}$. On the contrary, the following are lower: seasonal effort $E^{s}$; sustainably harvested stock size $X_{2}^{s}$; number of seasons required $\left(t\right.$, not $\left.t^{*}\right)$ to achieved the expected total stock value $E\left(V^{s}\right)$ (not the maximum $E\left(V^{s}\right)^{*}$ achievable at the optimal $s^{*}$ ); and the probabilities of success at achieving the total expected stock value or any portion of it. In other words, under any regulatory environment (represented here by $s$ ), profit $\left(\Pi^{s}\right)$ and output $\left(H^{s}\right)$ are in conflict with and must be traded off for job provision and long-term employment security $\left(E^{s}\right.$ and $\left.t\right)$, stock conservation $\left(X_{2}^{s}\right)$ and less risky harvesting $\left(\mathrm{P}\left(E\left(V^{s}\right)\right)\right.$. More importantly, the trade-off is not a nuclear option (all or nothing). It can be done incrementally and evaluated quantitatively.

The probabilities of success at achieving 50\%,75\%,100\%, 125\% and $150 \%$ of the maximum total expected stock value $E\left(V^{\wp}\right)^{*}$ (not the $E\left(V^{\wp}\right)$ under each simulated $s$ ) appear to drop a little after reaching their maximum before becoming impossible to achieve (beyond the feasibility limit for $s$ ). The reason is that as the reserve size increases and reaches its feasibility limit $(1-c / p q k)$, the seasonal harvest effort, output and profit and the total expected stock value drop abruptly. The rate of decline is much steeper than the rate of increase when the reserve size rises from zero. This decline in $E\left(V^{S}\right)$ is sufficiently large to overcome the reduction in the risk of stock collapse at high $s$, causing the probability of success at achieving $E\left(V^{s}\right)$ to drop slightly. Notice that the probability of achieving the maximum total expected stock value $E\left(V^{\varsigma}\right)^{*}$ at the optimal (most efficient) reserve size $s^{*}$ is $\mathrm{P}\left(E\left(V^{\varsigma}\right)^{*}\right)$ or $\mathrm{P}\left(t^{*}\right)$. It is not the same as the probability of achieving the total expected stock value $E\left(V^{\diamond}\right)$ at any other reserve size $s$, i.e., $\mathrm{P}\left(E\left(V^{s}\right)\right)$ or $\mathrm{P}(t)$. The reason is that the most efficient seasonal output, effort and profit under the optimum-harvesting regime are different for different reserve size. This will lead to a different total expected stock value, i.e., all discounted future harvest profits calculated at present.

Finally, at the reserve size's feasibility limit, all seasonal harvest effort, output and profit go to zero so there will be no total expected stock value to speak of. The probability of success becomes meaningless. Without harvesting, the biomass reaches its biological maximum carrying capacity $\left(X_{2}^{\mathrm{s}}\right)$. Notice that $X_{1}^{\mathrm{s}}$ and $X_{2}{ }^{\mathrm{s}}$ are both achievable and sustainable levels of the biomass. Since $X_{2}^{\mathrm{s}}>X_{1}^{\mathrm{s}}$, managers will always strive to achieve $X_{2}^{\mathrm{s}}$.

\section{Policy Implications}

Modern fisheries management should be objective-oriented and follow a partnership approach. Any committee of fishers, managers and community members must not see their differing and competing objectives as conflicting goals that can only be either one or the other (mutually exclusive). Instead, their desires or agendas must be laid bare to all concerned and subject to benign negotiations and agreeable trade-offs. Furthermore, the trade-offs should be done gradually (i.e., no objectives should be $0 \%$ or $100 \%$ satisfied) and be quantitatively transparent.

In this paper, I adopted a multi-period, marine-reserve-adjusted, and random-stock-collapse-prone modification of the original Schaefer model $(\mathrm{Li}, 2000)$. I then ran simulations on various common management objectives. The simulations were run on the principle of optimum harvesting (i.e., restricted entry and profit maximization). This uses the reserve size and fishing effort to balance the return (total derivable stock value) against risks (of random stock collapse and uncertainty in total derivable stock value).

The simulation results are two-fold. First, by maximizing total stock value, changes in the model parameters can drastically affect the outcomes of the common objectives. For example, a higher stock growth rate brings in substantially more economic benefits than a rise in market price, biomass or catch efficiency; whereas a higher harvesting cost could be devastating to the fishing community. Rising interest rates force the harvest fleet to work harder by both cutting harvest effort and fishing more intensively into the stock. Higher collapse risks bring about the exact opposite.

Second, by altering the regulatory environment (represented by the reserve size), I have shown that profit and output are in conflict with and must be traded off the following: job provision and long-term employment security, stock conservation and less risky harvesting. More importantly, the trade-off can be achieved gradually and 
incrementally. It is not merely either one or the other. It can also be quantitatively evaluated. An economically viable harvest return must balance against the risk of stock collapse and harvest uncertainty.

\section{Acknowledgements}

I am grateful for the financial support from the Department of Statistics and Actuarial Science at the University of Hong Kong.

\section{References}

BenDor, T., Scheffran J., \& Hannond, B. (2009). Ecological and economic sustainability in fishery management: A multi-agent model for understanding competition and cooperation. Ecological Economics, 68, 1061-1073. http://dx.doi.org/10.1016/j.ecolecon.2008.07.014

Greenstreet, S. P. R., Rogers, S. I., Rice, J. C., Piet, G. J., Guirey, E. J., Fraser, H. M., \& Fryer, R. J. (2011). Development of the EcoQO for the North Sea fish community. ICES Journal of Marine Science, 68(1), 1-11. http://dx.doi.org/10.1093/icesjms/fsq156

Hilborn, R. (2007). Moving to sustainability by learning from successful fisheries. Ambio, 36(4), 296-303 . http://dx.doi.org/10.1579/0044-7447(2007)36[296:MTSBLF]2.0.CO;2

Hockey, P. A. R., \& Branch, G. M. (1997). Criteria, objectives and methodology for evaluating marine protected areas in South Africa. South African Journal of Marine Science, 18, 369-383. http://dx.doi.org/10.2989/025776197784160884

Lauck, T., Clark, C. W., Mangel, M., \& Munro, G. R. (1998). Implementing the precautionary principle in fisheries management through marine reserves. Ecological Applications, 8(1), S72-S78. http://dx.doi.org/10.1890/1051-0761(1998)8[S72:ITPPIF]2.0.CO;2

Li, E. A. L. (2000). Optimum Harvesting with Marine Reserves. North American Journal of Fisheries Management, 20(6), 882-896. http://dx.doi.org/10.1577/1548-8675(2000)020<0882:OHWMR >2.0.CO;2

Methot, Jr. R. D., \& Wetzel, C. R. (2013). Stock synthesis: A biological and statistical framework for fish stock assessment and fishery management. Fisheries Research, 142, 86-99. http://dx.doi.org/10.1016/j.fishres.2012.10.012

Munro, G. R. (1996). Approaches to the economics of the management of high seas fishery resources: a summary. Canadian Journal of Economics, 29(April Special Issue), 157-164.

Novaczek, I. (1995). Possible roles for marine protected areas in establishing sustainable fisheries in Canada. In N. L. Shackell \& J. H. M. Willison (Eds.), Marine protected areas and sustainable fisheries (pp. 31-36). Centre for Wildlife and Conservation Biology, Acadia University, Wolfville, Nova Scotia, Canada.

Schaefer, M. B. (1954). Some aspects of the dynamics of populations important to the management of commercial marine fisheries. Bulletin of the Inter-American Tropical Tuna Commission, 1, 27-56. http://dx.doi.org/10.1139/f57-025

\section{Copyrights}

Copyright for this article is retained by the author(s), with first publication rights granted to the journal.

This is an open-access article distributed under the terms and conditions of the Creative Commons Attribution license (http://creativecommons.org/licenses/by/3.0/). 